\title{
APLIKASI ALGINAT SEBAGAI BAHAN PENGENTAL PADA PENCAPAN BATIK
}

\author{
Ellya Sinurat dan Murdinah*)
}

\begin{abstract}
ABSTRAK
Untuk mengetahui kemampuan natrium alginat hasil ekstraksi rumput laut jenis Sargassum filipendula sebagai bahan pengental pada pencapan batik, telah dilakukan serangkaian percobaan dan pencapan. Tahap awal telah dilakukan uji bahan baku alginat hasil ekstraksi dari Sargassum filipendula dan alginat komersial. Hasil analisis menunjukkan bahwa alginat hasil ekstraksi mempunyai viskositas 232 cPs (konsentrasi 1,5\% b/v), pH 6,7, kadar air 6,21\%, kadar abu 24,47\%, derajat putih $22,45 \%$, zat tak larut 2,1\%; sedangkan hasil analisis alginat komersial menunjukkan viskositas $100 \mathrm{cPs}$ (konsentrasi 1,5\% b/v), pH 7,2, kadar air 10,41\%, kadar abu 32,82\%, derajat putih $29,50 \%$ dan zat tak larut $1,23 \%$. Alginat hasil percobaan diaplikasikan pada pencapan batik dengan variasi konsentrasi $2,0 \%, 2,5 \%, 3,0 \%$ dan 3,5\%, sedangkan alginat komersial konsentrasinya adalah 3,0\%. Pencapan batik ini menggunakan bahan kain selulosa dengan zat pewarna reaktif. Pengujian yang dilakukan meliputi ketajaman motif, ketuaan warna, kekakuan kain, ketahanan luntur warna terhadap gosokan dan ketahanan luntur warna terhadap pencucian. Dari hasil pengujian tersebut diketahui bahwa alginat hasil percobaan dengan konsentrasi $2,5 \%$ mempunyai mutu yang sama dengan alginat komersial.
\end{abstract}

\section{ABSTRACT: Application of alginate as a thickening agent in batik printing. By: Ellya Sinurat and Murdinah}

\begin{abstract}
A series of experiments and batik printing has been done to determine the ability of the sodium alginate extracted from Sargassum filipendula as thickening agent in batik printing process. As initial step, analysis of alginate powder extracted from Sargassum filipendula and commercial alginate was carried out. The results showed that the viscosity was $232 \mathrm{cPs}$ (concentration $1.5 \% \mathrm{~b} / \mathrm{v}$ ), $\mathrm{pH}$ was 6.7 , moisture content was $6.21 \%$, ash content was $24.47 \%$, whiteness was $22.45 \%$ and undissolved total suspension was of $2.1 \%$. The commercial alginate powder analysis indicated the viscosity of $100 \mathrm{cPs}$ (concentration $1.5 \% \mathrm{~b} / \mathrm{V}$ ), $\mathrm{pH}$ of 7.2 , moisture content of $10.41 \%$, ash content of $32.82 \%$, whiteness of $29.50 \%$ and undissolved total suspension of $1.23 \%$. The product was then applied in printing of the batik made from cellulosa with various different concentrations $(2.0 \%, 2.5 \%, 3.0 \%$, and $3.5 \%)$ with a reactive dye. As a comparation, the commonly imported commercial alginate was used at concentration of $3.0 \%$. The assay included design strength, colour fastness, fabric stiffness, and colour fastness to wet and dry rubbing. The result of analysis showed that alginate extracted from Sargassum filipendula with concentration of $2.5 \%$ can be used as thickener, which was similar to the quality of commercial alginate.
\end{abstract}

KEYWORDS: Sargassum filipendula, thickening agent, batik printing, alginate

\section{PENDAHULUAN}

Natrium alginat berasal dari rumput laut coklat (brown seaweed) yang sifatnya bervariasi bergantung pada spesies masing-masing. Negara yang telah memanfaatkan alginat antara lain Scotlandia, Irlandia, Perancis, Cina, Amerika Serikat, Amerika Latin, Jepang dan Korea. Di Indonesia industri alginat belum berkembang, dan baru terdapat satu pengolah rumput laut coklat yaitu PT. Merlindo Rekamatra yang berlokasi di Bandung. Industri ini lebih menekankan pada teknologi formulasi dan blending. Alginat diekspor dalam bentuk asam alginat ke Jepang, Cina, Singapura dan Mesir dengan rata-rata ekspor alginat sebanyak 79,3 ton per tahun. Negara tujuan ekspor terbesar yaitu Mesir dengan volume rata-rata 41,3 ton per tahun. Walaupun Indonesia telah mengekspor alginat ke beberapa negara, tetapi untuk memenuhi kebutuhan dalam negeri terutama industri tekstil dan industri lainnya masih harus mengimpor alginat dalam jumlah yang cukup besar, yaitu pada tahun 2004 sebesar $1.169 .034 \mathrm{~kg}$ (Anggadiredja et al., 2006).

\footnotetext{
*) Peneliti pada Balai Besar Riset Pengolahan Produk dan Bioteknologi Kelautan dan Perikanan,DKP
} 
Di Indonesia rumput laut coklat sebagai sumber daya potensial yang banyak tumbuh secara alami di perairan Indonesia adalah jenis Sargasum dan Turbinaria. Ketersediaan dan kualitas bahan baku alginat perlu ditingkatkan untuk mendukung berkembangnya industri alginat di dalam negeri. Peluang ini sangat terbuka karena alginat merupakan salah satu hidrokoloid dari rumput laut yang banyak digunakan dalam berbagai industri, seperti tekstil, kertas, cat, farmasi dan makanan serta minuman.

Pada industri tekstil, alginat digunakan sebagai pengental pada proses pencapan batik. Pada pencapan batik, alginat dicampur dengan zat warna reaktif atau zat warna dispersi. Pada pasta pencapan, bagian yang terbesar adalah pengental dengan porsi $80 \%$ atau lebih berfungsi sebagai media dan berperan sebagai pengantar zat warna masuk ke dalam serat dan mencegah terjadinya migrasi agar motif warna tetap tajam (Zubaidi et al., 2004).

Sampai saat ini pada pencapan batik masih digunakan alginat yang diimpor dari China sebagai pengental. Apabila alginat impor tersebut dapat diproduksi di dalam negeri, maka dapat meningkatkan nilai tambah rumput laut, mengurangi ketergantungan impor, menghemat devisa negara dan menciptakan lapangan kerja.

Hasil penelitian penggunaan produksi PT. K.R sebagai bahan pengental pada industri tekstil dalam negeri diperoleh hasil pencapan yang mutunya sama jika menggunakan alginat komersial produk China (Mutia et al., 2002). Penelitian ini bertujuan untuk mengetahui kemampuan alginat hasil percobaan dari rumput laut Sargasum filifendula sebagai pengental pada pencapan kain dan sebagai pembanding digunakan alginat produk impor. Secara teknis penggunaan pengental harus memenuhi beberapa syarat, antara lain : tidak berwarna, tidak bereaksi dengan zat warna dan zat pembantu, mudah dihilangkan dalam proses pencucian dan mempunyai kekentalan yang stabil dalam waktu tertentu (Komarudin, 2002).

\section{BAHAN DAN METODE}

\section{Bahan}

1. Bahan baku rumput laut Sargassum filipendula diperoleh dari daerah Pantai Binuangeun, Kecamatan Malingping, Kabupaten Lebak, Provinsi Banten

2. Kain selulosa siap celup dengan konstruksi : anyaman polos, No. Lusi 14,2 Tex, No. pakan 14 Tex, Tetal lusi/cm 54 helai, tetal pakan/cm 27 helai dan berat $/ \mathrm{m}^{2} 118 \mathrm{gram}$.
3. Zat warna reaktif golongan monoklorotriazina ex. PT. ICl : Chloranyl Yellow P-4G, Chloranyl Orange P-8B dan Chloranyl Blue P-5R.

4. Bahan Pengental : alginat hasil ekstraksi dari rumput laut Sargasum filipendula, dan alginat komersial produksi China.

\section{Natrium bikarbonat}

\section{Peralatan}

Peralatan yang digunakan antara lain gelas piala, gelas ukur, penangas air, penyaring vibrator, termometer, pengaduk, mixer, spatula, oven, saringan plastik, timbangan, kertas $\mathrm{pH}$, screen bermotif, steaming machine, viskometer, $\mathrm{pH}$ meter, whiteness meter, spectroflash 500, kasa pencapan datar, crockmeter, setrika, launderometer, dan stiffness tester.

\section{Metode}

Penelitian ini dibagi menjadi 3 tahapan yaitu :

1. Ekstraksi alginat menggunakan metode ekstraksi alginat dari rumput laut Sargassum filipendula (Murdinah et al., 2005) yang dimodifikasi (penggunaan bahan pemutih dari kaporit menjadi natrium hipoklorit).

2. Karakterisasi mutu alginat hasil percobaan dan alginat komersial yang meliputi parameter : $\mathrm{pH}$ (menggunakan $\mathrm{pH}$ meter), kadar air dan kadar abu (AOAC, 1984), zat yang tidak larut, derajat putih (menggunakan whiteness meter) dan viskositas (menggunakan viskometer Brookfield).

3. Aplikasi formula pasta pada batik dan untuk mengetahui mutu hasil pencapan dilakukan uji secara laboratorium. Pada tahap pembuatan pasta pengental digunakan variasi konsentrasi alginat hasil percobaan yaitu: $2,0 \%, 2,5 \%, 3,0 \%$, dan $3,5 \%$. Sebagai pembanding digunakan alginat komersial dengan konsentrasi 3,0\%. Formula standar pasta pencapan yang digunakan seperti tertera pada Tabel 1. Rancangan percobaan yang digunakan adalah rancangan acak lengkap dengan satu faktor yaitu konsentrasi alginat dengan dua kali ulangan (Santosa, 2004). Parameter mutu hasil pencapan yang diuji adalah : persentase ketajaman motif berdasarkan rumus : $\mathrm{A} / 19 \times 100 \%$, dimana $A$ adalah panjang motif hasil pencapan (Amirudin, 1987), uji ketuaan warna (Judd \& Wyszecky, 1967), uji kekakuan kain berdasarkan SNI 08-0314-1998, uji tahan luntur warna terhadap gosokan berdasarkan SNI 08-0288-1998, dan uji tahan luntur warna terhadap pencucian berdasarkan SNI 08-0285-1998.

\section{Prosedur pencapan pada batik :}

Pada tahap awal dilakukan persiapan cetakan dengan meletakkan screen bermotif di atas meja yang 
Tabel 1. Formulasi standar pasta pencapan

Table 1. Standard formula of printing paste

\begin{tabular}{lc}
\hline \multicolumn{1}{c}{ Bahan/Ingredients } & $\begin{array}{c}\text { Konsentrasi dalam air/ } \\
\text { Concentration in water }\end{array}$ \\
\hline Natrium bikarbonat/Na Bicarbonate & $1.0 \%$ \\
Alginat/Alginate & $3.0 \%$ \\
Pewarna reaktif/Reactive dye & $2.8 \%$ \\
\hline
\end{tabular}

sudah dilapisi kain (setting meja). Kemudian dilakukan pembuatan pasta pengental dengan cara melarutkan alginat ke dalam air sebanyak 1 liter, diaduk sampai homogen. Setelah homegen, larutan tersebut ditambah zat warna reaktif kemudian diaduk kembali sampai homogen yang disebut larutan pasta. Larutan pasta yang dibuat dituang ke atas screen bermotif lalu dilakukan pencapan pada kain. Kain yang sudah dicap kemudian dikeringkan dengan cara dianginanginkan selama 1 malam. Setelah itu dilakukan perebusan dengan suhu $102^{\circ} \mathrm{C}$ selama 8 menit. Lalu dicuci dan dibilas sampai bersih. Selanjutnya kain hasil pencapan dikeringkan dengan cara dianginanginkan. Skema diagram alir proses pencapan dapat dilihat pada Gambar 1.

\section{HASIL DAN BAHASAN}

\section{Karakteritik Alginat Hasil Percobaan dan Alginat Komersial}

Alginat hasil percobaan mengandung kadar air $6,21 \%$, kadar abu $24,47 \%, \mathrm{pH} 6,7$ dan viskositas 232 cPs. Kadar air dan kadar abu alginat hasil percobaan masih memenuhi standar mutu alginat industrial grade untuk kadar air berkisar 5-20\% dan kadar abu berkisar 18-27\% (Winarno, 1996). Karakteristik alginat yang penting diketahui adalah viskositas, karena viskositas akan menentukan kekentalan alginat. Pada industri tekstil alginat dapat digunakan sebagai bahan pengental. Alginat hasil percobaan termasuk alginat

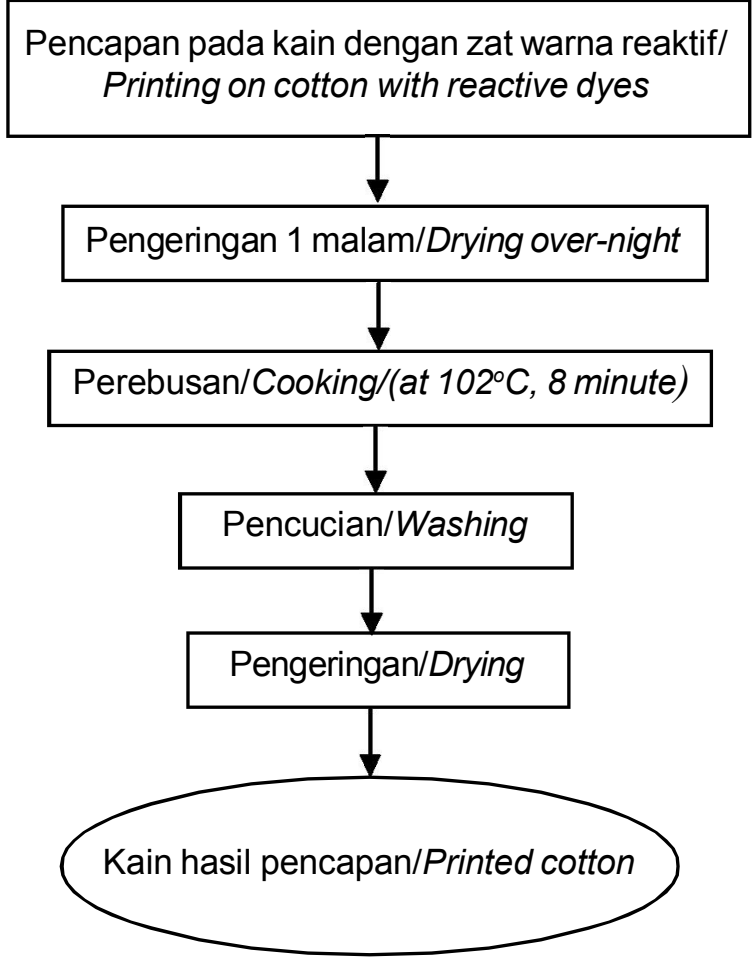

Gambar 1. Diagram alir proses pencapan pada batik.

Figure 1. Flow chart process of batik printing. 
yang mempunyai viskositas rendah, karena viskositasnya berada di antara 20-400 cPs (Winarno, 1996), namun bila dibandingkan dengan alginat komersial nilai viskositas hasil percobaan masih lebih tinggi karena nilai viskositas alginat komersial sebesar 100 cPs. Hal ini kemungkinan disebabkan karena jenis rumput laut yang digunakan sebagai bahan baku untuk alginat berbeda dan proses ekstraksi yang dilakukan berbeda. Dari karakteristik viskositas dapat diasumsikan penggunaan alginat hasil percobaan dapat digunakan sebagai pengental pada aplikasi pencapan batik dalam jumlah lebih sedikit bila dibandingkan alginat komersial. Karakteristik mutu alginat hasil percobaan dan alginat komersial dapat dilihat pada Tabel 2.

\section{Aplikasi pada Pencapan}

\section{Ketajaman motif}

Hasil pengukuran ketajaman motif menunjukkan nilai untuk semua perlakuan hampir sama yaitu berkisar 102,2-102,9 \% (Gambar 2). Hasil uji statistik menunjukkan bahwa perlakuan konsentrasi alginat hasil percobaan tidak berpengaruh terhadap ketajaman motif hasil pencapan. Apabila dibandingkan dengan hasil pencapan dengan pengental alginat komersial (102\%), maka semua perlakuan ini sama. Dengan demikian, secara umum ketajaman motif hasil pencapan dengan kedua jenis bahan pengental tersebut sama dan nilainya baik. Dalam hal ini alginat

Tabel 2. Karakteristik alginat hasil percobaan dan alginat komersial

Table 2. Characteristic of experimental alginate and commercial alginate

\begin{tabular}{lcc}
\hline \multicolumn{1}{c}{ Parameter/Parameters } & $\begin{array}{c}\text { Alginat hasil } \\
\text { percobaan/ } \\
\text { Experimental } \\
\text { alginate }\end{array}$ & $\begin{array}{c}\text { Alginat komersial/ } \\
\text { Commercial alginate }\end{array}$ \\
\hline $\mathrm{pH}$ & $6.70 \pm 0.5$ & $7.22 \pm 0.07$ \\
Kadar air/Moisture content (\%) & $6.21 \pm 0.06$ & $10.41 \pm 0.08$ \\
Kadar abu/Ash content (\%) & $24.47 \pm 0.06$ & $32.82 \pm 0.05$ \\
Zat yang tidak larut/Undissolved substance (\%) & $2.10 \pm 0.02$ & $1.23 \pm 0.02$ \\
Derajat putih/Whiteness (\%) & $22.45 \pm 0.05$ & $29.50 \pm 0.02$ \\
Viskositas/Viscosity (cPs) & $232.00 \pm 1.4$ & $100.00 \pm 1.2$ \\
\hline
\end{tabular}

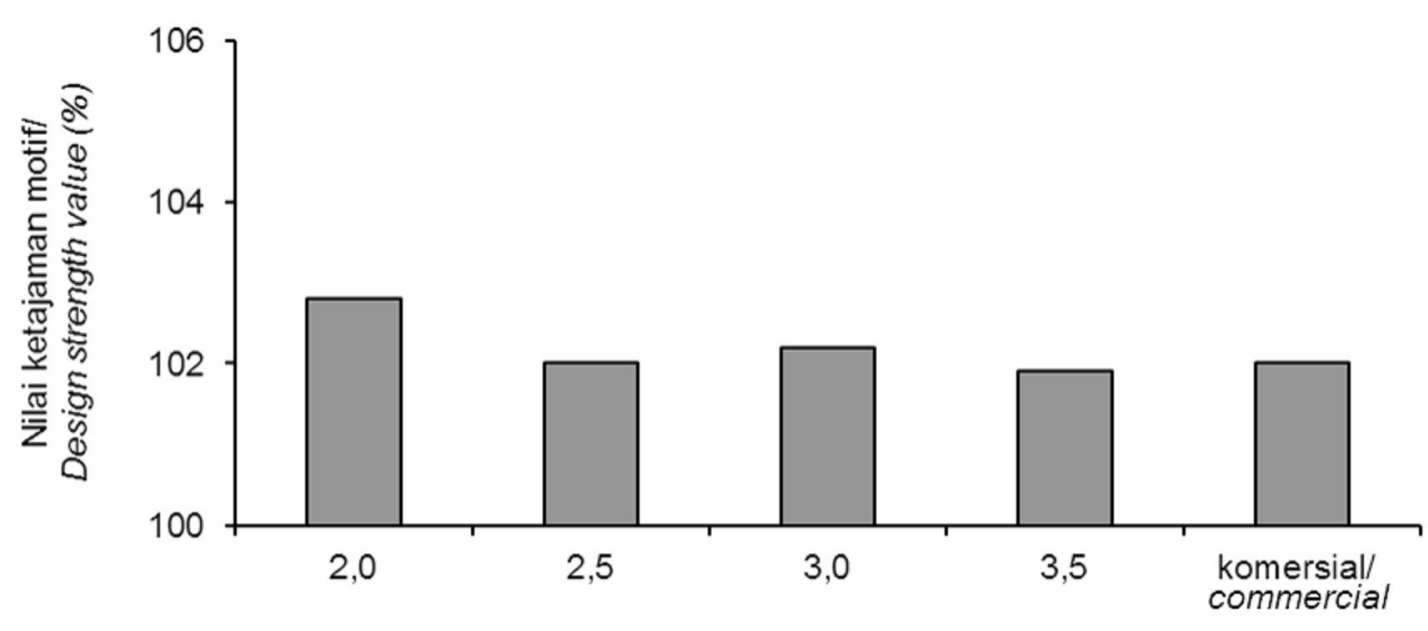

Konsentrasi alginat/Alginate concentration (\%)

Gambar 2. Hasil analisis ketajaman motif.

Figure 2. Result of analysis of design strength. 


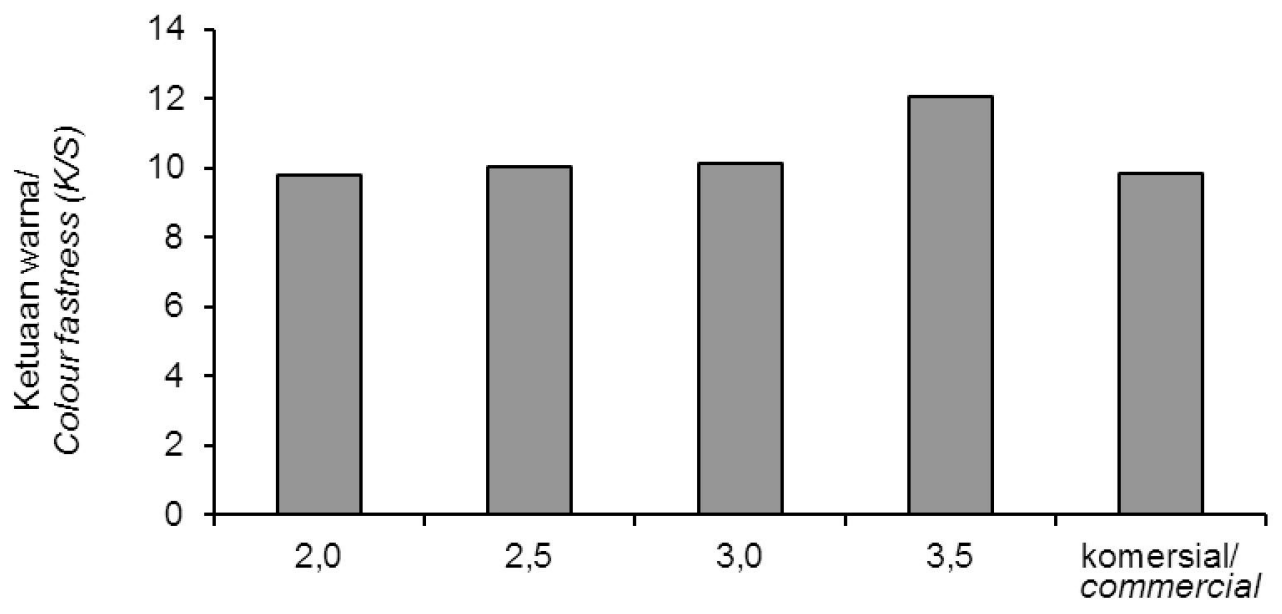

Konsentrasi alginat/Alginate concentration (\%)

Gambar 3. Hasil analisis ketuaan warna.

Figure 3. Result of analysis of colour fastness.

hasil percobaan sudah berfungsi dengan baik sebagai pengental pada pasta pencapan yaitu berperan sebagai pengantar zat warna masuk ke dalam serat dan mencegah terjadinya migrasi zat warna sehingga warna tetap tajam (Zubaidi et al., 2004).

\section{Ketuaan warna}

Nilai ketuaan warna hasil pencapan dari berbagai konsentrasi alginat percobaan berkisar antara 9,8012,01 (Gambar 3).

Uji ketuaan warna hasil pencapan menunjukkan ada kecenderungan dengan semakin tinggi konsentrasi alginat dalam pasta pencapan akan menaikkan nilai ketuaan warna. Hasil uji statistik menunjukkan bahwa hanya perlakuan konsentrasi alginat 3,5\% yang berbeda nyata dibandingkan alginat komersial $(10,09)$. Hal ini karena semakin tinggi konsentrasi alginat daya penetrasi zat warna relatif lebih besar sehingga zat warna lebih banyak terserap oleh kain yang menyebabkan warna hasil pencapan menjadi lebih tua.

\section{Kekakuan kain}

Hasil pengukuran kekakuan kain dari hasil pencapan dengan alginat hasil percobaan menunjukkan nilai antara 67,61-93,71 mg.cm

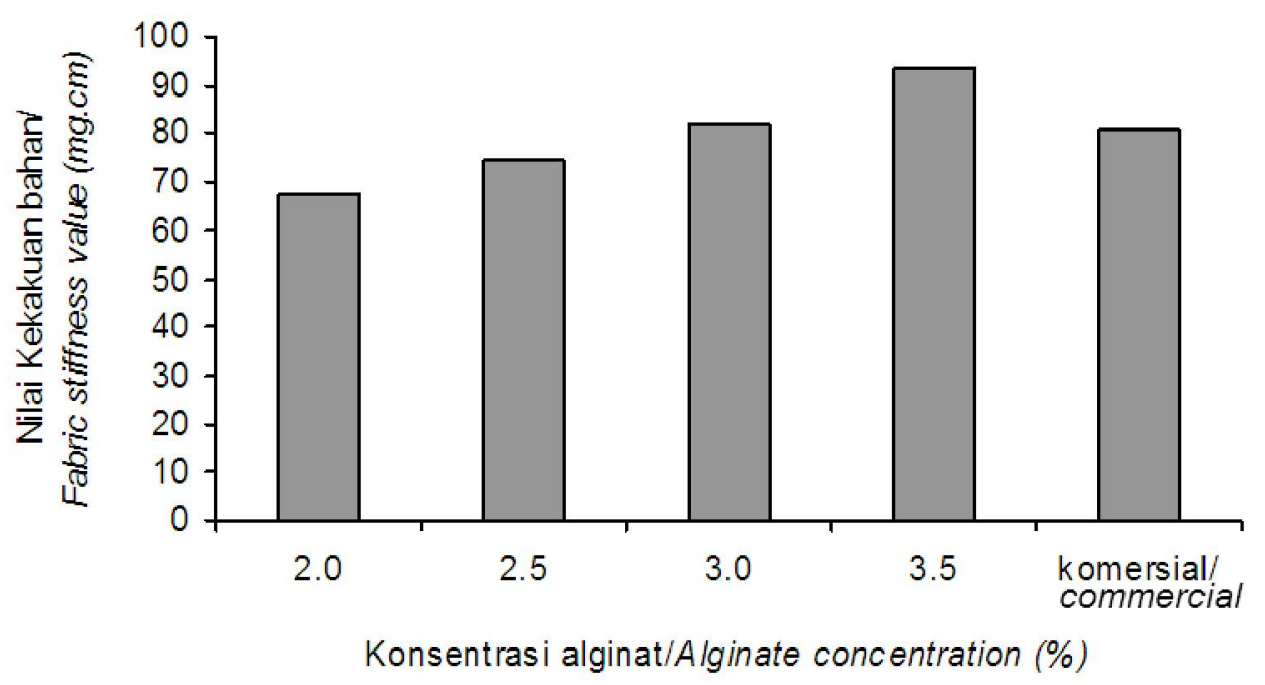

Gambar 4. Hasil analisis kekakuan kain.

Figure 4. Result of analysis of fabric stiffness. 
(Gambar 4). Dari data tersebut terlihat bahwa semakin tinggi konsentrasi alginat dalam pasta pencapan mengakibatkan kekakuan kain hasil pencapan semakin tinggi.

Kekakuan kain terendah diperoleh pada hasil pencapan dengan penggunaan alginat 2,0\%, yaitu sebesar $67,61 \mathrm{mg} . \mathrm{cm}$ dan tertinggi pada penggunaan alginat $3,5 \%$ sebesar $93,71 \mathrm{mg} . \mathrm{cm}$. Secara statistik perlakuan konsentrasi alginat memberikan pengaruh yang nyata terhadap kekakuan kain hasil pencapan. Apabila dibandingkan dengan hasil pencapan dengan alginat komersial (80,9 mg.cm), ternyata perlakuan penggunaan konsentrasi alginat hasil percobaan 2,0\% sampai 3,0\% memiliki nilai kekakuan kain lebih rendah. Hal ini disebabkan karena alginat mudah larut dalam pencucian, sehingga zat yang tertinggal dalam kain hanya pewarna. Semakin tinggi nilai kekakuan kain, maka semakin rendah mutu kain hasil pencapan (Djufri et al., 1976).

\section{Ketahanan luntur warna hasil pencapan}

Untuk mengetahui ketahanan luntur warna hasil pencapan alginat hasil percobaan dan alginat komersial, telah dilakukan pengujian ketahanan luntur warna terhadap pencucian dan gosokan.

\section{Ketahanan luntur warna terhadap pencucian}

Uji luntur warna terhadap pencucian adalah sangat penting untuk menentukan dapat atau tidaknya pengental digunakan. Perlakuan variasi konsentrasi alginat percobaan tidak berpengaruh nyata terhadap tahan luntur warna terhadap pencucian. Apabila dibandingkan dengan alginat komersial $(4,5)$, maka semua perlakuan ini sama. Nilai uji ketahanan luntur warna terhadap pencucian dari jenis pengental alginat percobaan dan alginat komersial disajikan pada Gambar 5.

Dari Gambar 5 terlihat bahwa, ketahanan luntur warna terhadap pencucian hasil pencapan dengan kedua jenis pengental memberikan hasil yang sama. Hasil yang diperoleh masih termasuk katagori baik (nilai 4,5), sesuai sifat zat warnanya, yang berarti kedua pengental tersebut sudah berfungsi dengan baik. Adanya daya tahan pencucian yang baik disebabkan zat warna terfiksasi dengan baik dan adanya ikatan kovalen yang kuat antara zat warna reaktif dengan serat, sedangkan zat warna yang tidak terfiksasi ke dalam serat dapat terlepas dengan mudah saat proses pencucian. Hasil penelitian Mutia et al. (2002) juga menunjukkan ketahanan luntur warna terhadap pencucian hasil pencapan dari alginat lokal dan alginat komersial (manutex RS dan manutex F) yang memberikan hasil yang sama.

\section{Ketahanan luntur warna terhadap gosokan}

Hasil uji luntur warna terhadap gosokan hasil pencapan dengan kedua jenis pengental disajikan pada Gambar 6. Dari Gambar 6 terlihat bahwa, ketahanan luntur warna terhadap gosokan hasil

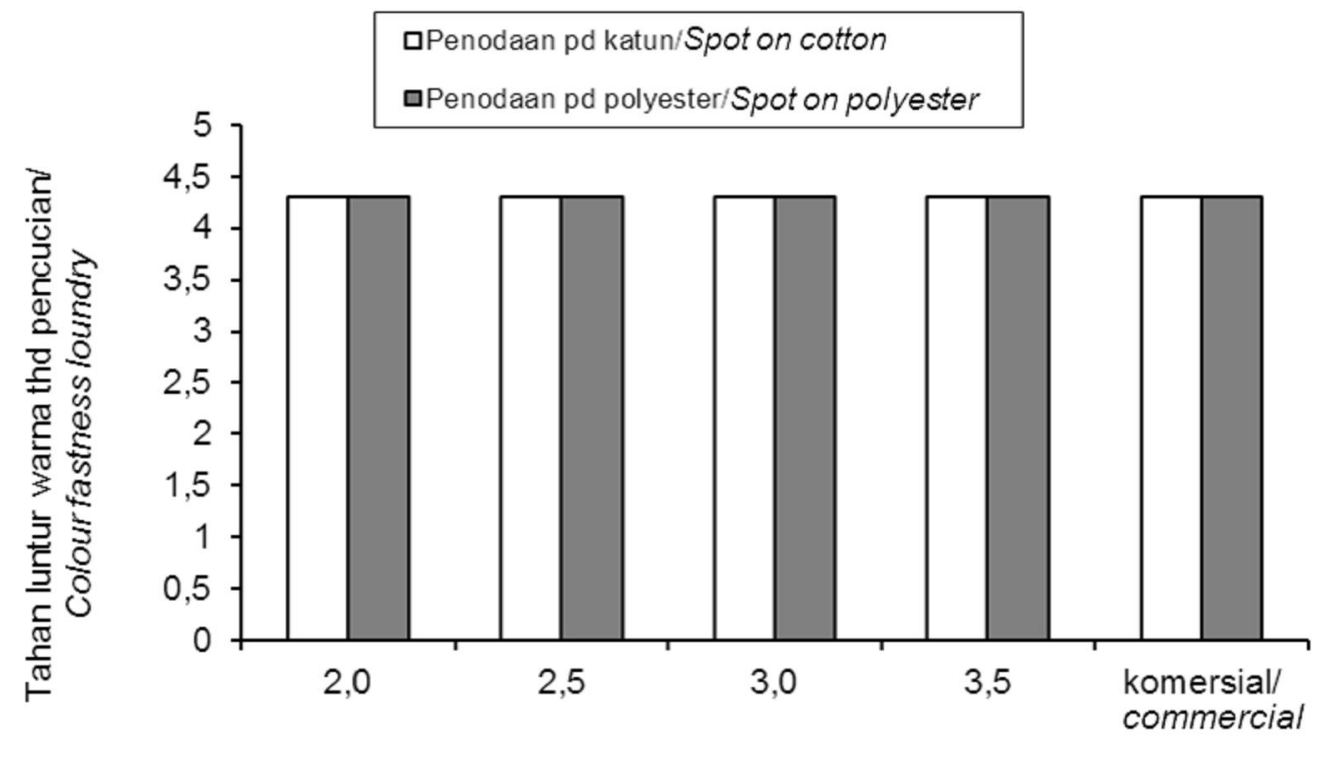

Konsentrasi alginat/Alginate concentration (\%)

Gambar 5. Hasil analisis ketahanan luntur warna terhadap pencucian.

Figure 5. Result of analysis of colour fastness loundry. 


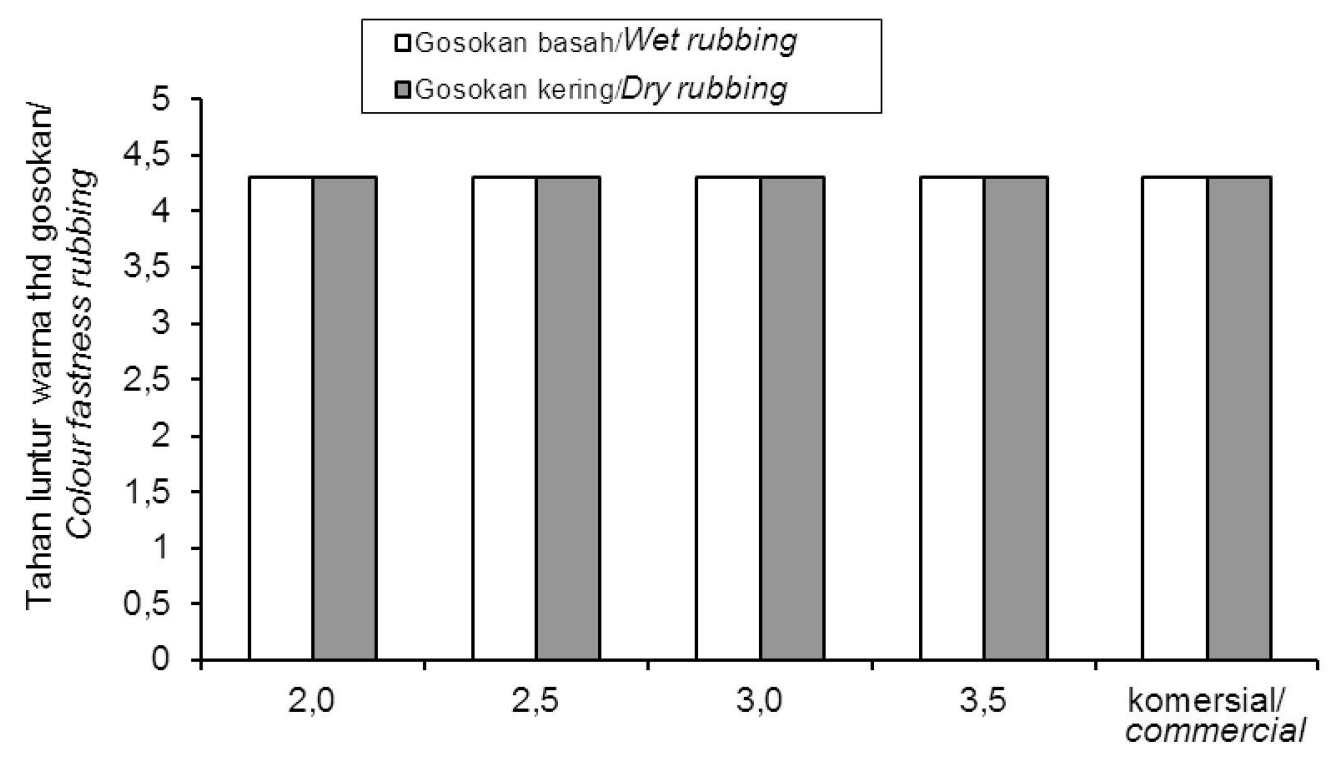

Konsentrasi alginat/Alginate concentration (\%)

Gambar 6. Hasil analisis ketahanan luntur warna terhadap gosokan.

Figure 6. Result of analysis of colour fastness rubbing.

pencapan dengan kedua pengental memberikan hasil yang sama $(4,5)$.

Perlakuan variasi konsentrasi alginat hasil percobaan tidak ber pengaruh nyata terhadap ketahanan luntur terhadap gosokan. Apabila dibandingkan dengan alginat komersial $(4,5)$, ternyata semua perlakuan ini memiliki nilai ketahanan luntur warna terhadap gosokan sama. Hal ini menunjukkan hasil pencapan dengan pengental alginat hasil percobaan dan alginat komersial menghasilkan produk dengan kualitas yang sama. Hal ini disebabkan semua sisa-sisa zat warna yang berada pada permukaan serat dapat dihilangkan pada pencucian.

\section{KESIMPULAN}

Dari hasil penelitian ini dapat diambil kesimpulan bahwa pada konsentrasi yang sama yaitu pada $1,5 \%$ (b/v) alginat hasil percobaan mempunyai viskositas $232 \mathrm{cPs}$, sedangkan alginat komersial $100 \mathrm{cPs}$. Alginat hasil percobaan dengan konsentrasi 2,5\% mempunyai mutu yang sama dengan alginat komersial berdasarkan uji mutu ketajaman motif, ketuaan warna, kekakuan kain, ketahanan luntur warna terhadap pencucian dan gosokan. Alginat hasil pecobaan dapat digunakan sebagai pengganti alginat komersial sebagai pengental pada pasta pencapan.

\section{DAFTAR PUSTAKA}

Amirudin. 1987. "Pengujian Pasta Cap". Arena Tekstil No.5., Balai Besar Tekstil Bandung. p. 30-37
Anggadiredja J.T., Achmad, Z., Heri, P., dan Sri Istini. 2006. Rumput Laut. Penebar Swadaya, Jakarta.147 pp.

AOAC. 1984. Official Method of Analysis of the Associates of Official Analytical Chemist. 14 ed $^{\text {th }}$ A.O.A.C. Inc Arlington Virginia. 1018 pp.

Djufri, R., Kasoenarno, G., Salihima, Astini, dan Lubis, A. 1976. Teknologi Pengelantangan, Pencelupan dan Pencapan. Institut Teknologi Tekstil, Bandung. 335 $\mathrm{pp}$.

Judd, D.B. and Wyszecky, G. 1967. Color in Business, Science and Industry, John Willey and Sons Inc., N.Y., $553 \mathrm{pp}$.

Komarudin, A. 2002. Pengaruh Waktu Penyimpanan Pasta Cap Natrium Alginat dan Campuran Natrium Alginat-Emulsi terhadap Hasil Pencapan Rayon Viskosa Menggunakan Zat Warna Reaktif. Skripsi. Sekolah Tinggi Teknologi Tekstil. Bandung.106 pp.

Murdinah, Amini, S., Irianto, H.E., Darmawan, M., Subaryono dan Sinurat, E. 2005. Laporan Teknis Riset Optimasi Pemanfaatan Makro dan Mikro Algae. Bagian Proyek Riset Pengolahan Produk dan Sosial Ekonomi Kelautan dan Perikanan. Jakarta. $109 \mathrm{pp}$.

Mutia, T., Amirudin, dan Darso. 2002. Perbandingan penggunaan alginat dalam negeri sebagai pengental pada pencapan kapas. Balai Besar Penelitian dan Pengembangan Industri Tekstil. Bandung. Arena Tekstil. 37(2): 23-30.

Santoso, S. 2004. Mengolah Data Statistik Secara Profesional. PT. Gramedia Pustaka Utama. Jakarta. $583 \mathrm{pp}$.

SNI 08-0314-1998. Cara Uji Kekakuan Bahan. Pusat Standarisasi Industri. Departemen Perindustrian Indonesia. 6 pp. 
SNI 08-0288-1998. Cara Uji Luntur Warna terhadap Pencucian. Pusat Standarisasi Industri. Departemen Perindustrian Indonesia. $10 \mathrm{pp}$.

SNI 08-0285-1998. Cara Uji Luntur Warna terhadap Gosokan. Pusat Standarisasi Industri. Departemen Perindustrian Indonesia. $3 \mathrm{pp}$.
Winarno F.G. 1996. Teknologi Pengolahan Rumput Laut Pustaka Sinar Harapan. Jakarta.111 pp.

Zubaidi, Masitoh, E. dan Waluyo, N. 2004. Penelitian pengental berbasis sumber daya alam untuk pencapan zat warna procion red H. Arena Tekstil. 19(1):1-38. 